\title{
Tableaux croisés : le marché de la peinture, entre sociologie de l'art et histoire culturelle
}

Entretien avec Julie Verlaine

Double Perspective: The Art Market-Between the Sociology of Art and Cultural History. A Conversation with Julie Verlaine

Tablas de contingencia : el mercado de la pintura, entre sociología del arte e historia cultural. Entrevista con Julie Verlaine realizada por Séverine Sofio

\section{Séverine Sofio et Julie Verlaine}

\section{(2) OpenEdition}

\section{Journals}

Édition électronique

URL : http://journals.openedition.org/bssg/290

DOI : $10.4000 /$ bssg.290

ISSN : $2490-9424$

Éditeur

Presses universitaires de Vincennes

Référence électronique

Séverine Sofio et Julie Verlaine, «Tableaux croisés : le marché de la peinture, entre sociologie de l'art et histoire culturelle», Biens Symboliques / Symbolic Goods [En ligne], 3 | 2018, mis en ligne le 15 octobre 2018, consulté le 04 mars 2021. URL : http://journals.openedition.org/bssg/290 ; DOI : https://doi.org/10.4000/bssg.290 
Tableaux croisés : le marché de la peinture, entre sociologie de l'art et histoire culturelle

Entretien avec Julie Verlaine
Double Perspective:

The Art Market-Between the Sociology of Art and Cultural History A Conversation with Julie Verlaine

Séverine Sofio

traduction | translation

Delaina Haslam

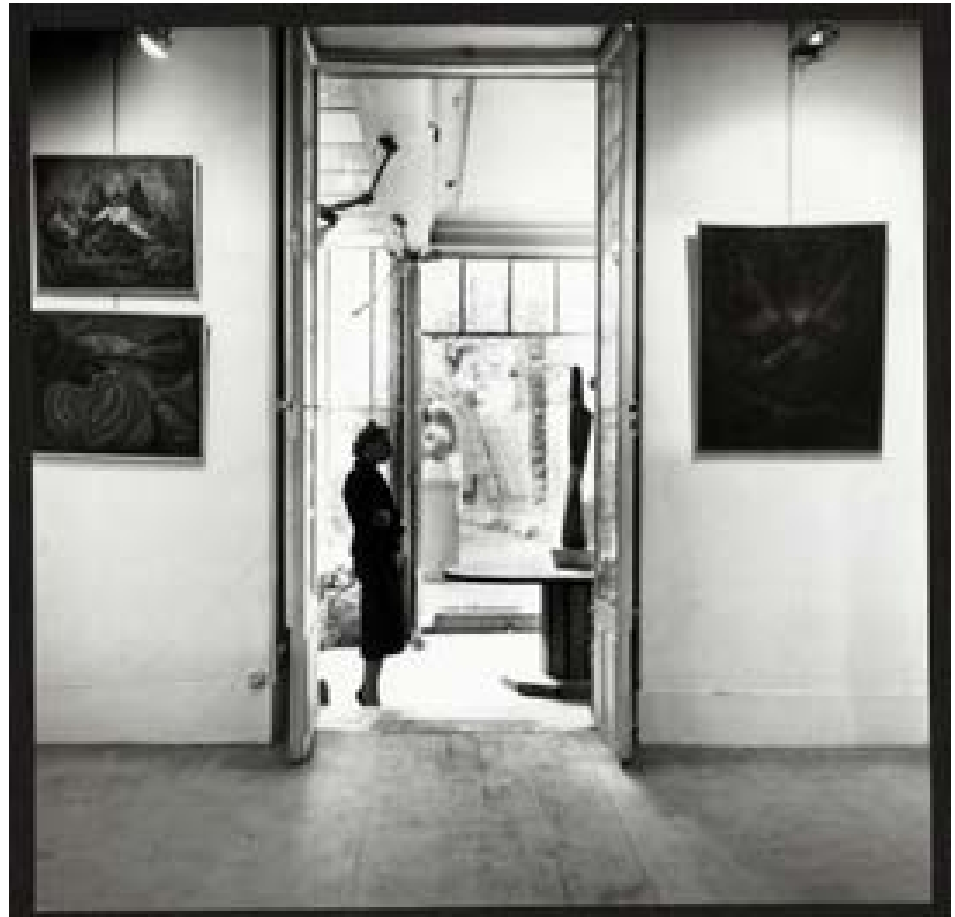

Illustration 1. À la Galerie Colette Allendy, à Paris, début des années 1950 / At Galerie Colette Allendy in Paris, in the 1950s. 
Séverine Sofio (S. S.) : - Vous êtes spécialiste d'histoire culturelle. Pour commencer, pourriez-vous expliquer rapidement ce qu'est cette spécialité au sein de l'histoire?

Julie Verlaine (J. V.) : L'histoire culturelle est fille de l'histoire des mentalités (portée par des auteurs comme Georges Duby ou Maurice Agulhon) et de l'histoire politique telle qu'elle a été renouvelée dans les années 1990 dans le sillage de René Rémond par des chercheurs comme Pascal Ory et Jean-François Sirinelli. C'est la rencontre de ces deux traditions historiographiques qui a fait apparaître ce qu'on a appelé l'« histoire culturelle ». II s'agit d'une histoire sociale des représentations et des sensibilités collectives : son objectif est de retracer l'histoire des acteurs et des vecteurs des représentations collectives qu'on va regrouper sous le terme générique de «culture » (sous-entendue : commune). Elle consiste dans l'étude des idées, des objets, de la culture dite populaire comme de la culture dite élitiste. Elle s'intéresse fortement aux normes sociales et aux systèmes de valeurs (le beau/le laid, le pur/ l'impur...), et tout particulièrement aux goûts et aux imaginaires : comment sont-ils construits ? transmis ? contestés ? réinventés? Enfin, l'histoire culturelle donne un primat à l'acteur sur l'œuvre, c'est-à-dire qu'elle étudie plutôt les individus et les structures, les activités et les politiques, les discours et les idéologies, que les œuvres pour elles-mêmes. En France, des historien-ne's aussi différent·ess que Daniel Roche, Roger Chartier, Christophe Charle, Dominique Kalifa, Pascal Ory et Pascale Goetschel se sont réclamé·e·s ou se réclament encore de l'histoire culturelle.

S. S. : - Le point commun entre ces historien 'ne.s fort différent $\cdot e \cdot s$ dans leurs parcours ou leurs objets de recherche, pourrait effectivement être une ouverture particulière aux autres disciplines des sciences humaines et sociales...
Séverine Sofio (S. S.): - You are a specialist in cultural history. Could you start by briefly introducing this speciality within French history?

Julie Verlaine (J. V.): - Cultural history originates, on the one hand, from the "history of mentalities," introduced by Georges Duby and Maurice Agulhon, and, on the other, from political history, as it was revisited in the 1990s by scholars such as Pascal Ory and Jean-François Sirinelli, following René Rémond. It is the encounter between these two historiographical traditions that led to the emergence of what we now call "cultural history." It is a social history of collective representations and sensitivities: its goal is to retrace the history of actors and bearers of collective representations, which we group under the umbrella term of "culture" (by which we mean, implicitly, "common" culture). It entails the study of ideas and objects, of both "popular" and "elitist" culture. Its main focus lies in social norms and value systems (what is beautiful/what is ugly, what is pure/what is impure...), and, in particular, in taste and the imaginary: how are these constructed, passed on, contested, and reinvented? Finally, cultural history gives priority to the producer, rather than to what is produced. In other words, cultural history studies individuals and structures, activities and policies, discourses and ideologies, rather than artworks themselves. In France, historians as diverse as Daniel Roche, Roger Chartier, Christophe Charle, Dominique Kalifa, Pascal Ory, and Pascale Goetschel align themselves with cultural history, or have done so in the past.

S. S.: - What these historians have in common, despite their very different backgrounds and research focuses, might actually be a significative openness to other disciplines within the humanities and social science... 
J. V. : - L'histoire culturelle est avant tout une histoire sociale : le dialogue avec les autres sciences sociales fait partie de l'ADN de I'histoire culturelle, ne serait-ce que parce que les objets auxquels nous nous intéressons, nous les partageons avec d'autres disciplines. D'ailleurs, comme je travaille sur les galeries et le marché de l'art, je suis souvent présentée comme historienne de l'art. Cela dit, je ne suis presque jamais présentée comme sociologue... ce qui est étrange, au fond, car, dans mes méthodes de travail ou dans mon approche de l'art comme objet de recherche, qui implique de mettre totalement de côté les notions de génie de l'artiste ou l'idée de valeur intrinsèque de l'œuvre, je me sens souvent plus proche des sociologues que des historien.ne.s de l'art.

Plus globalement, en histoire ces dernières années, beaucoup de gens se sont mis à dire qu'ils faisaient de l'histoire culturelle de quelque chose (histoire culturelle du politique, du genre, de l'économie etc.) et de nombreux postes àl'Université sont aujourd'hui intitulés " Histoire sociale et culturelle de (tel ou tel domaine) 》. En fait, je crois que c'est surtout le signe que les approches en termes d'histoire des représentations, longtemps cantonnées au domaine de la culture, ont été importées au sein de différents champs d'étude. On assiste à un élargissement - et peut-être même à une dilution - de ce qu'est l'histoire culturelle, actuellement, en termes d'objets (culture, représentations, imaginaires...) ; néanmoins il semble important de rappeler ses fondements méthodologiques, et en particulier son attachement très fort aux méthodes de l'histoire sociale et plus largement des sciences sociales (enquêtes, statistiques, observation participante...).

S. S. : - De votre côté, vous avez consacré votre thèse de doctorat à l'histoire des galeries d'art en France entre 1945 et les années 1960. Or, ce sujet avait fait l'objet d'une enquête d'ampleur de la part d'une sociologue, Raymonde Moulin. Agrégée d'histoire, inscrite en thèse de sociologie sous la direction de Raymond
J. V.: - Cultural history is, first and foremost, a social history: the dialogue with other disciplines within social science is part of cultural history's DNA, simply because we all share an interest in the same topics. In fact, since I work on art galleries and the art market, I am often introduced as an art historian. That being said, I am almost never introduced as a sociologist. This is strange, after all, because in my methods and in the way I deal with art as a subject of investigation-which entails putting aside notions of genius or the idea of an artwork having an intrinsic value - I often consider myself closer to sociologists than to art historians. More broadly, over the past few years, quite a few historians have started saying that they study the cultural history of something (the cultural history of the political, of gender, of the economy...) and several university posts are now entitled "social and cultural history of (such and such a topic)." Actually, I believe this shows that the perspectives opened up by the history of representations, which had long been confined solely to the field of culture, have now been imported into various other study fields. We are witnessing an expansion-and perhaps even a dilution - of the objects that make up cultural history today (culture, representations, the imaginary, and so on). Yet, it may be worth recalling its methodological principles, especially its very strong attachment to the methods of social history and, more generally, social science (interviews, statistics, participant observation, and so on).

S. S.: - Your PhD thesis focused on the history of art galleries in France between 1945 and the 1960s. This topic had already been the subject of a large-scale study by sociologist Raymonde Moulin. 
Aron dès le début des années 1950, Raymonde Moulin a mené une longue enquête dans les galeries d'art. Sa thèse, Le Marché de la peinture en France, est parue sous la forme d'un imposant ouvrage en 1967 aux Éditions de Minuit, dans la collection dirigée par Pierre Bourdieu qui était alors son collègue au Centre d'études sociologiques. L'enquête de Moulin, qui était pionnière à bien des égards (on y reviendra), est donc doublement intéressante pour vous qui reprenez le même objet cinquante ans plus tard: dans ce contexte, Le Marché de la peinture en France a-t-il été une source historique pour votre travail ou une enquête sociologique dont vous avez pu vous inspirer et que - en quelque sorte - vous avez revisitée depuis une autre perspective disciplinaire?

J. V. : - J'ai commencé à m'intéresser aux travaux de Raymonde Moulin en 2006, c'est-à-dire assez rapidement au cours de ma recherche doctorale, car il n'y avait rien ou presque, à part ses publications, sur le marché de l'art en France après la guerre. Elle s'intéressait aux marchés de l'art, dans la mesure où elle a travaillé à la fois sur les galeries, les ventes aux enchères, les commissaires-priseurs, le courtage, etc., tandis que mon étude se limitait aux galeries elles-mêmes, mais à part cela, son sujet et le mien sont les mêmes. Le livre de Moulin fourmille de données chiffrées précieuses pour une étude historique, et je m'en suis beaucoup servie. En revanche, l'anonymisation des enquêtés et des extraits d'entretien rend son utilisation difficile pour une connaissance plus factuelle. Mais je me suis énormément inspirée des typologies qu'elle dégage : elle a eu l'idée de caractériser ses acteurs en types sociaux, en mettant non pas le modèle du négociant, mais celui de l'entrepreneur, inspiré de Schumpeter, au centre de ses réflexions. Comme tout est anonyme chez Moulin, dégager des idéaux-types grâce à l'observation et aux entretiens était ce qui lui a permis d'analyser un groupe social dont on ne sait alors rien d'autre que ce qu'elle en dit.
After having obtained the agrégation ${ }^{1}$ in history and enrolled as a PhD student in sociology under the supervision of Raymond Aron in the 1950s, Raymonde Moulin began her inquiry on art galleries. Her thesis, Le Marché de la peinture en France, was published as a book in 1967 by Éditions de Minuit ${ }^{2}$, as part of the collection edited by Pierre Bourdieu, who was her colleague at the Centre d'études sociologiques at the time. Moulin's research, which was groundbreaking in many respects (we will return to this), is thus doubly interesting for you as you go back to study the same subject fifty years later: with this in mind, has The French Art Market been a historical source for your work, or a sociological inquiry to use as inspiration, and one that you have revisited to some extent from a different disciplinary perspective?

J. V.: - I first started reading Raymonde Moulin's work in 2006, quite early on in my $\mathrm{PhD}$, since, aside from her publications, almost nothing had been written on the art market in France after the war. Moulin investigated art markets, in the plural: she worked on galleries, auctions, auctioneers, brokerage, and so on; whereas my study was limited to art galleries themselves. Other than that, the subject is the same. Moulin's book is full of quantitative data that are invaluable for a historical study - I definitely made use of that On the other hand, since all names and interview excerpts have been anonymized, it is hard to use them as factual sources. That said, I drew much inspiration from the typologies she identifies: she had the idea of characterizing her actors through social types, placing not the model of the merchant, but that of the entrepreneur,

1 The agrégation is the most prestigious and competitive teaching exam in France.

2 The book was published in English in 1987 (The French Art Market: A Sociological View. English translation by Arthur Goldhammer) by Rutgers University Press. See Raymonde Moulin's selective bibliography at the end of this conversation. 
La différence essentielle entre nos deux recherches, c'est que, contrairement à elle, j'ai pu avoir accès aux archives des galeries, qui avaient été entretemps déposées dans des centres publics (à la Bibliothèque Kandinsky au Centre Pompidou, aux Archives nationales...) ou privés (Institut Mémoires de l'édition contemporaine]). Mon objectif était de combiner une approche quantitative (en relevant toutes les galeries existantes à Paris, leur adresse, leurs programmes d'exposition, et en étudiant leurs activités à l'aide d'une base de données) et une approche qualitative, fondée sur des études de cas rendues justement possibles par l'accessibilité récente des archives (plus artistiques et administratives qu'économiques, à mon grand regret).

Mais, je me suis beaucoup appuyée sur les méthodes de Raymonde Moulin, et il me semble avoir posé à ce microcosme des acteurs culturels des années d'après-guerre les mêmes questions qu'elle : pourquoi existe-t-il un "marché » de l'art ? quels liens les différents protagonistes, artistes, marchands et collectionneurs, entretiennent-ils ensemble ? peut-on esquisser une théorie de la fabrication de la valeur artistique à partir de l'observation de ce milieu social ? D'ailleurs, j'ai parfois eu la chance de rencontrer, à cinquante ans d'écart, des acteur.rice-s et des témoins avec lesquelles Moulin s'était entretenue comme Jean-François Jaeger, Denise René ou Maurice Garnier, et j'ai repris en partie à cette occasion le plan d'entretien semi-directif qu'elle présente à la fin du Marché de la peinture.

S. S. : - Outre ce plan d'entretien, qu'avez-vous repris et adapté, vous qui êtes historienne, de l'enquête sociologique de Moulin? inspired by Schumpeter, at the core of her analysis. By coming up with some ideal types from observation and interviews, she managed to analyse a social group about which we know nothing other than what she tells us.

The main difference between our studies is that, unlike her, I had access to the art galleries' archives, which had since then been transferred to other institutions, whether public (the Kandinsky Library at the Centre Pompidou or the French National Archives [http://www.archives-nationales.culture.gouv.fr/]) or private (the Institut Mémoires de l'édition contemporaine). My aim was to bring together a quantitative approach (identifying all existing art galleries in Paris, their address, and their exhibition programme, as well as studying their activities with the help of a database) and a qualitative approach based on case studies, which was made possible by the recent accessibility of archives (which, much to my regret, were mostly artistic and administrative archives, rather than economic ones). But I drew extensively on Raymonde Moulin's methods, and I feel that I have asked the same questions she asked of that microcosm of cultural actors in the post-war period: why is there an art "market"? What kind of relationships do the various protagonists-artists, dealers, and collectors-have with each other? Is it possible to develop a theory of the production of artistic value starting from the observation of this social environment? Incidentally, I have had the chance to meet some of the actors and witnesses to whom Moulin spoke fifty years earlier, such as JeanFrançois Jaeger, Denise René, and Maurice Garnier, and, on those occasions, I partly referred back to the semi-structured interview guide she included at the end of The French Art Market.

S. S.: - Besides this interview guide, as a historian, what did you take, or adapt, from Moulin's sociological inquiry? 
J. V. : - Ses méthodes d'enquête étaient extrêmement pionnières. Raymonde Moulin a été la première sociologue à s'intéresser au marché de l'art contemporain, elle a donc dû innover à bien des égards. Ses méthodes et ses questionnements sont souvent à cheval entre histoire et sociologie : il faut se rappeler qu'elle était historienne de formation, et en parallèle à son enquête sur le marché de la peinture, elle travaillait sur les expositions d'art en province dans les années 1880 . Ce que j'ai particulièrement retenu et repris de ses méthodes de travail, outre la rigueur et le sens de la nuance, ce sont des exemples de méthodologie mixte: elle a su associer la quantification et l'enquête orale par exemple. Il faut dire qu'elle a affronté des défis majeurs : c'est la première à avoir étudié les artistes en tant que groupe social, dans une belle entreprise scientifique d'identification et de dénombrement d'une population aux frontières floues. Dans ses livres, elle a aussi le courage de dire que ce milieu - le marché de l'art, et plus largement le monde de l'art contemporain - est plein de tabous, d'opacité et de mauvaises pratiques. Elle a mis en œuvre une « fréquentation sans exclusive " (c'est son expression) des galeries, des salons, des ventes aux enchères, etc., avec cette idée que le chercheur ou la chercheuse doit connaître parfaitement, intimement, son terrain, et s'y intégrer au point d'en maîtriser tous les codes, même les plus implicites - sans perdre son regard critique, bien sûr. Or le marché de l'art compte parmi les milieux les plus codifiés et les plus exclusifs qui soient, ce qui rend cette «immersion " assez ardue. C'est un véritable modèle d'enquête dont je propose à mes étudiant'e.s de s'inspirer.

Enfin, son livre est une excellente illustration de la manière dont on peut monter en généralité à partir d'une enquête sur des vies singulières. Elle a étudié le marché de la peinture en s'intéressant d'abord à des personnes. Ce qui l'intéresse, ce sont des individus, leurs initiatives et leurs conceptions : c'est-à-dire (bien avant que Howard Becker le théorise) la chaîne des acteurs qui dans un
J. V.:-Her research methods were extremely innovative. Raymonde Moulin was the first sociologist to tackle the contemporary art market, so she had to innovate in many respects. Her methods and her research questions often lie between history and sociology: we must bear in mind that she was a historian by training, and that, alongside her research on the art market in Paris, she was working on art exhibitions in the provinces in the 1880s. What I especially appreciated and retained from her methodology, besides rigour and sensitivity to nuances, were her examples of mixed methods: for instance, she managed to combine quantification and oral inquiry. She also faced some serious challenges: she was the first scholar to study artists as a social group, thus making an important scientific contribution by quantifying and identifying a population with fairly fuzzy boundaries. In her books, she also has the courage to say that this social environment-the art market and, more broadly, the contemporary art world-is filled with taboos, a lack of transparency, and malpractice. She carried out "non exclusive attendance" ("fréquentation sans exclusive" to use her expression) of galleries, art fairs and exhibitions, auctions, and so on, with the idea that researchers need to have a perfect knowledge of their field, and must integrate to the point of mastering all the codes, even the most implicit ones, without losing their critical outlook, of course. The art market is among the most codified and exclusive environments, which makes this "immersion" quite hard. I encourage my students to take her study as a model and draw inspiration from it.

Finally, her book is a perfect illustration of how we can draw general conclusions based on an inquiry into individual lives. She studied the art market by focusing on people first. What interests her are individuals, their initiatives and conceptions, that is to say (long before Howard Becker theorized it) the chain of actors who, within the same field, contribute, each in their own way and from different positions, to the construction of value. From there, she 
même espace social contribuent, chacun à leur manière et depuis des positions distinctes, à la construction de la valeur. À partir de là, elle est la première à poser des questions telles que : qu'est-ce qui fait le succès ? comment la réussite économique influe-t-elle la création artistique ? etc. Autant de questions qui sont devenues les fondements-mêmes de la sociologie de l'art. La fascination de Moulin pour Van Gogh est à l'origine de ces interrogations : on voit dans la correspondance de Van Gogh combien sa dépendance au marché a influencé sa création. Ce phénomène nouveau date à peine des années 1880 : à partir de cette époque, le marché est devenu une condition de la création contemporaine. Un nouveau système se met en place.

S. S. :- Pourtantily a des différences entre les approches historiques et sociologiques d'un même objet - par exemple, l'anonymisation (ou pas) des données, que vous mentionniez tout à l'heure : il s'agit là d'un des points de divergence les plus évidents entre les deux disciplines. Il est inconcevable pour un'e historien.ne d'anonymiser ses données, alors que cette opération va (à peu près) de soi pour un.e sociologue travaillant sur un terrain contemporain.

J. V. : - Chez Moulin, effectivement, les entretiens sont essentiels et tout est anonyme (l'anonymisation est d'ailleurs si bien faite que, même en connaissant très bien le monde sur lequel Moulin a enquêté, je ne suis pas arrivée à identifier tout le monde !). Mais, même anonymes, les extraits d'entretien sont très bien recontextualisés, ce qui fait qu'on saisit parfaitement les enjeux car elle a réussi à dépersonnaliser les propos sans en perdre la substance. Son intérêt reste les pratiques professionnelles, et c'est pour cela qu'elle a travaillé à partir d'idéaux-types : cela rend son propos très clair et efficace. Dans le livre, les extraits d'entretien ont été, pour moi, non des sources factuelles mais une manière de valider ce que je trouvais dans les archives ou dans was the first to ask questions such as: what makes success? How does economic success influence an artist's creation? And so on. Questions that are now the very founding principles of the sociology of art. Moulin's fascination with Van Gogh led her to these questions: in Van Gogh's letters we see to what extent his dependency on the market influenced his creation. This is a new phenomenon that dates back to the 1880s at the earliest: from then on, the market became a condition of contemporary creation. A new system was put in place.

S. S.: - However, there are some differences between historical and sociological approaches to the same subject. Take for example the anonymization of sources you mentioned earlier: that is one of the clearest differences between the two disciplines. For a historian, anonymizing data is inconceivable, whereas that goes (almost) without saying for a sociologist doing fieldwork today.

J. V.: - Indeed, interviews are an essential part of Moulin's work and everything is left anonymous (she did that so skilfully, by the way, that eventough I knew very well the environment she studies, I have not managed to identify everybody!). Yet, albeit anonymous, the interview excerpts are perfectly recontextualised, so that we can still have a perfect grasp of the issues at stake. In fact, she really manages to depersonalize statements. She is interested in professional practices, that is why she works with ideal typesand that is also what makes her argument clear and effective. The interview excerpts quoted in the book were useful to me not as factual sources, but as a way of validating what I was finding in archives or in my own interviews. In a sense, I did the opposite 
mes entretiens par ailleurs. D'une certaine manière, j'ai procédé à l'inverse de Raymonde Moulin, qui est allée des acteurs à l'analyse des pratiques. Je suis partie des pratiques (et de leurs traces laissées dans les archives) pour pouvoir resituer les marchands d'art dans leur réalité, et ainsi faire le lien entre la construction de la réputation et la construction de la valeur. À ce propos, d'ailleurs, Moulin a proposé une définition très ouverte du marché de l'art : pour elle, les galeries sont d'abord des lieux culturels avant d'être des lieux marchands. Elle a une analyse très fine des relations entre marchands, artistes et collectionneurs, soulignant dans ses ouvrages combien l'approche doit en être dynamique, car ces réseaux se croisent, se reconfigurent, évoluent sans cesse. Elle procède aussi à une étude approfondie des ventes publiques, des transactions - ce que je n'ai pas abordé. Son analyse est très théorique dans la mesure où elle avait peu de données chiffrées à sa disposition. Aujourd'hui encore, tout cela est fort mal connu...

S. S. : - L'enquête de Raymonde Moulin sur le marché de la peinture, qui fut rééditée (quoique - bizarrement - jamais en format poche), est devenue proprement matricielle : elle a posé les bases méthodologiques et les questionnements théoriques de toutes les enquêtes futures sur le sujet. II faut rappeler qu'au moment où Moulin publie son livre, la sociologie de l'art en France se résume au travail de Pierre Francastel, qui est encore imprégné d'esthétique, et l'histoire sociale de l'art en est encore à ses balbutiements, fortement teintés de critique marxiste, dans la suite des ouvrages d'Arnold Hauser. Moulin est donc la première à appliquer au marché de l'art des méthodes à la fois qualitatives et quantitatives, inspirées de l'économie, de l'histoire, de l'ethnologie et de la sociologie des organisations. Or, parce qu'elle empruntait à plusieurs disciplines, justement, sa méthode a été jugée assez durement par la sociologie à l'époque de la parution du livre. Mais qu'en est-il dans le petit monde des galeries de la fin des années of Raymonde Moulin, who went from actors to the analysis of practices. In my case, I started from practices (and the traces they had left in the archives) to resituate art dealers in their reality, and thus draw the connection between the construction of reputation and the construction of value. On this point, Moulin provided a very open definition of the art market: for her, galleries are first of all cultural places before they are economic ones. She carries out a very careful and detailed analysis of the relationships between dealers, artists, and collectors, and in her work she emphasizes that the approach needs to remain dynamic, as these networks are deeply entangled, and undergo endless reconfigurations and evolutions. She also carried out an in-depth study of public sales and transactions, which I could not cover. Her analysis is very theoretical since she had little quantitative data at her disposal. Actually all this is still very poorly understood today...

S. S.: - Raymonde Moulin's study of the art market, which has been republished several times (although, strangely, never in paperback), has become a veritable model: she laid down the methodological bases and the theoretical questions for all future studies on this topic. We must bear in mind that, at the time when Moulin published her book, the sociology of art in France could be summed up by Pierre Francastel's work, which was still soaked in aesthetics, while the social history of art was in its infancy and had a strong flavour of critical Marxism, after Arnold Hauser's works. Moulin has thus been the first to apply both qualitative and quantitative methods to analyse the art market, drawing on the economy, history, ethnology and the sociology of organizations. The thing is, precisely because she was borrowing from several disciplines, her methodology was judged rather negatively by sociologists when her book was published. But what about the small world of art galleries at the end 
1960 ? Avez-vous des éléments sur la réception du travail de Moulin par ceux qu'elle a étudiés?

J. V. : - Oui. Par exemple, Raymonde Moulin théorise le concept de " galerie-pilote », un néologisme forgé par René Berger, lors du « premier Salon international des galeries pilotes » qui se tient à Lausanne en 1963. L'idée est de réunir, dans une manifestation collective, des galeries " modernistes ", engagées auprès des artistes afin de lutter contre la légende noire des marchands de tableaux. On est au moment où commence à apparaître le vocable de gallerist ou galeriste, préféré à dealer ou marchand. Moulin est invitée à ce Salon et y prononce une formidable conférence sur la fonction de la galerie-pilote définie comme un «type idéal »: elle étudie la justification du rôle proprement artistique de la galerie dans son rôle de soutien des jeunes artistes, de défense et promotion des talents, et de " certification » de la valeur des œuvres contemporaines. J'ai trouvé des marques importantes de (re)connaissance du travail de Moulin, à ce moment, de la part de ces marchands qui vont ensuite créer les grandes foires internationales d'art contemporain, notamment en Suisse, avec le regard tourné vers les États-Unis. Cela contraste avec le relatif oubli, ou la méconnaissance, aujourd'hui, sinon de ses travaux, du moins de leur caractère absolument pionnier.

S. S. : - Et en termes de résultats, avez-vous noté des points de divergence entre votre travail et l'étude de Moulin?

J. V. : - II y en a quelques-uns. J'ai par exemple été amenée à nuancer certaines conclusions de Raymonde Moulin notamment autour de la place de Paris, à l'époque, sur le plan international. En effet, elle a étudié Paris comme un microcosme et considéré les galeries parisiennes comme un système fermé, ce qui, d'un côté, se justifie, mais ce qui, d'un autre côté, l'a empêchée de voir of the 1960s? Do you know how Moulin's work was received by the people she studied?

J. V.: - Yes I do. For instance, Raymonde Moulin theorized the concept of "pilot gallery," a neologism created by René Berger at the time of the first Salon international des galeries pilotes, which was held in Lausanne in 1963. The idea was to organize a collective event to bring together "modernist" galleries committed to artists, in the fight against the disrepute of painting dealers. At this time, in fact, the term "gallerist" was beginning to make its appearance and replace the term "dealer." In this context, Moulin gave a great speech on the function of the pilot gallery, defined as an ideal type: she studied how the gallery's strictly artistic role finds its justification within its role supporting young artists, protecting and promoting talents, and "certifying" the value of contemporary works. I found evidence that, at the time, Moulin's work was known and appreciated by those dealers who would later create the most famous international shows of contemporary art fairs, especially in Switzerland, with an eye towards the United States. However today, in contrast, the totally pioneering nature of her work, if not her work itself, is relatively neglected or unknown.

S. S.: - Do the results of your work differ from those of Moulin's study?

J. V.: - A little. For example, I had to qualify some of Raymonde Moulin's conclusions, in particular those regarding the role of Paris on the international scene at the time. She dealt with Paris as a microcosm and with Parisian art galleries as a closed system. On the one hand, there are good reasons to do that, but, on the other, this prevented her from seeing broader evolutions, most 
des évolutions plus générales, en particulier les liens avec d'autres galeries ailleurs qu'en France. Elle est ainsi un peu passée à côté du fait que l'art de cette époque est déjà ancré dans un espace transnational, constitué de métropoles culturelles engagées dans des échanges permanents où se font jour des influences, des rivalités et des surenchères. Avoir une perspective internationale change un peu la vision des choses, notamment dans l'étude du premier marché et de l'importance des galeries dans les carrières des artistes. Or désormais on sait aujourd'hui que dès les années 1950 , les marchands parisiens sont sous influence des marchands aux États-Unis, et dépendent grandement d'eux. Si son terrain n'avait pas été seulement parisien, Raymonde Moulin aurait vu que la hiérarchie qu'elle étudiait, était, d'une part, prise dans une autre hiérarchie à l'échelle internationale, et, d'autre part, en train de s'effondrer. Par exemple, Moulin ne voit pas que si Jean Dubuffet réussit si bien à Paris, c'est avant tout parce que ses marchands français sont en lien avec un galeriste états-unien, Pierre Matisse, le fils de l'artiste Henri Matisse, qui vend et donne ses œuvres au Museum of Modern Art. Cela empêche Moulin, dans certains cas, d'attribuer les bonnes causes aux effets qu'elle analyse. Les aspects internationaux sont venus plus tard dans sa réflexion et elle a consacré plusieurs essais à la mondialisation, et plus généralement à l'inscription spatiale - à diverses échelles, du local au global - des activités artistiques.

Un autre point que Raymonde Moulin n'a pas du tout exploré (mais je précise que c'est vraiment accessoire par rapport à tout ce que ses travaux ont apporté !), c'est la question du goût et de l'esthétique. Elle met au centre de son étude le couple binaire art figuratif/art non figuratif, mais son histoire du marché n'a jamais été une histoire des goûts et de la formation des goûts artistiques. Cela ne disqualifie en rien son enquête, évidemment : on ne peut pas tout étudier en une seule recherche ! Par ailleurs, l'enquête de Pierre Bourdieu et Alain Darbel (en collaboration avec Dominique notably the relations that linked those galleries with others outside of France. She thereby failed to see that the art of that time was already taking place in a transnational space made up of cultural metropolises engaged in constant exchanges, which gave rise to mutual influences, rivalries, and overbids. An international perspective changes the outlook slightly, especially for the study of the first market and the importance of galleries for artists careers. We now know that Parisian dealers had been under the influence of dealers in the United States since the 1950s, and that they were very dependent on them. Had her fieldwork not been limited to Paris, Raymonde Moulin would have seen that the hierarchy she was studying was caught up in another hierarchy at the international level, while, at the same time, moving towards dissolution. For example, Moulin fails to see that, if Jean Dubuffet had so much success in Paris, it was mainly because his French dealers were in contact with an American gallerist, Pierre Matisse, son of the artist Henri Matisse, who would sell and give his works to the Museum of Modern Art. In some cases, this prevents Moulin from ascribing the right causes to the effects she studies. Moulin started to consider international aspects later on in her career: she then devoted several essays to globalization and, more generally, to the spatial embeddedness of artistic activities, from the local to the global scale.

Another point that Raymonde Moulin has not explored at all (but I should emphasize that this is a very minor point compared with everything that her works have contributed to the field!) is the question of taste and aesthetics. She places the binary opposition of figurative/non-figurative art at the core of her study, but her history of the market is not a history of tastes, or of the construction of artistic tastes. Of course, this in no way diminishes the importance of her study: one cannot possibly do everything in a single piece of research! Plus, The Love of Art, a study of art museums and their 
Schnapper) sur les musées d'art et leur public, L'Amour de l'art, publiée dans la même collection l'année précédente, en 1966, abordait ces thématiques-là, en lien avec l'institution patrimoniale. Pour le marché de l'art, il s'agit encore de problématiques qui restent à creuser, à partir du travail de Raymonde Moulin : comment évoluent les représentations collectives et les normes du goût ? Comment expliquer les choix esthétiques des marchands ? Comment faire le lien entre le fonctionnement du marché de l'art et la construction des goûts ? Moulin se penche sur les artistes, les marchands, leurs relations, etc., mais l'œuvre comme objet culturel, c'est-à-dire comme lieu de constructions culturelles, ne l'intéresse pas. En tout cas comme chercheuse.

Quoi qu'il en soit, il faut inviter nos collègues et nos étudiant·e.s à lire et relire ses travaux, ainsi que l'ouvrage collectif dirigé par Pierre-Michel Menger et Jean-Claude Passeron et intitulé L'Art de la recherche, foisonnant hommage de ses élèves à leur directrice de recherche.

S. S. : - Dans une conférence récente à la Bibliothèque nationale de France, Pierre-Michel Menger montre justement très bien pourquoi Le Marché de la peinture en France fait partie du canon de la sociologie de l'art. Du reste, au vu de la carrière de Raymonde Moulin - entrée au CNRS à une époque où les chercheuses y étaient fort peu nombreuses, pionnière longtemps seule dans son domaine, spécialiste estimée par les professionnel/le.s du marché de l'art et par les artistes (ses entretiens avec Dubuffet, par exemple, n'ont malheureusement jamais été publiés), directrice du département de sociologie de l'Université de Vincennes dans la foulée de Mai 68, fondatrice et directrice du Centre de Sociologie des Arts à l'École des hautes études en sciences sociales (EHESS) à Paris, membre du Conseil artistique des musées de France (en charge de superviser les acquisitions des musées nationaux) puis du Comité d'histoire du ministère de la Culture, première femme à la public by Pierre Bourdieu and Alain Darbel (in collaboration with Dominique Schnapper), published as part of the same collection the previous year, 1966, tackled these topics in relation to heritage institutions. As for the art market, these are some of the questions that remain to be explored on the basis of Raymonde Moulin's work: how do collective representations and norms of taste evolve? How can we explain dealers' aesthetic choices? How can we draw the link between the functioning of the art market and the construction of taste? Moulin focuses on artists, dealers, their relations, and so on, but she is not interested in artwork as a cultural object, that is as a space of cultural constructions. At least, not as a scholar. In any case, we should encourage our students and colleagues to read and reread her work, as well as the edited volume by sociologists Pierre-Michel Menger and Jean-Claude Passeron titled L'Art de la recherche, a rich tribute from her students to their director of studies.

S. S.: - In a recent talk at the French National Library, PierreMichel Menger explains very clearly why The French Art Market constitutes a model for the sociology of art. Moreover, Raymonde Moulin joined the French National Centre for Scientific Research (CNRS) at a time when there were very few female scholars; for a long time she remained a lone pioneer in her field; she was a specialist renowned both by professionals of the art market and by artists (regrettably, her interviews with Jean Dubuffet have never been published); she served as the director of the Department of Sociology at the University of Vincennes in the wake of May 1968, as founder and director of the Centre de Sociologie des Arts at the École des hautes études en sciences sociales (EHESS) in Paris; and as a member of the Conseil artistique des musées de France (wich is the committee in charge of artworks' acquisitions for French national art galleries), then of the Comité d'histoire du ministère 
tête de la Société française de sociologie (aujourd'hui Association française de sociologie) et de la Revue française de sociologie -, on ne peut s'empêcher de se dire que, si Moulin avait été un homme, elle jouirait sans doute d'une reconnaissance professionnelle plus importante aujourd'hui.

J. V. : - Absolument. II est vrai que, en comparaison du nombre d'articles scientifiques dont elle est l'auteure depuis les années 1960, Raymonde Moulin a publié assez peu de livres. II y a eu $L e$ Marché de la peinture en France, en 1967. Elle est ensuite auteure ou co-auteure de plusieurs rapports sur les artistes, les architectes et les politiques de soutien à la création - des travaux qui n'ont pas été publiés ou sont restés confidentiels. Ce n'est qu'en 1992, alors que Moulin est retraitée, qu'elle publie L'Artiste, l'institution et le marché, issu de la grande enquête sur la condition des artistes en France, menée par l'équipe du Centre de sociologie des arts dans les années 1980, avec là encore des méthodes tout à fait originales. Maintes fois réédité (en poche, cette fois !), L'Artiste, l'institution et le marché est resté, là encore, une référence incontournable et ce même si les données qui y sont analysées étaient déjà légèrement obsolètes au moment de leur parution. Peu de temps après, en 1995, est publié son recueil d'articles De la valeur de l'art, au moment où le monde de l'art contemporain en France traverse une crise profonde. Enfin, en 2003, paraît son dernier livre Le Marché de l'art. Mondialisation et nouvelles technologies, un ouvrage assez court, qui montre qu'à presque 80 ans, Raymonde Moulin est toujours très au fait de l'actualité du marché de l'art international. Elle y analyse toutes les nouvelles configurations du de la Culture (History Committee of the Ministry of Culture); she was the first woman in charge of the professional association of French sociologists (known today as the Association française de sociologie), and was later in charge of one of the most prestigious French reviews of sociology, the Revue française de sociologie. Considering all this, we cannot help but think that, if Moulin were a man, she would probably enjoy more professional recognition today.

J. V.: - Absolutely. It is true that, compared with the number of scientific articles she has written since the 1960s, she published only a few books. The first was Le Marché de la peinture en France in 1967. After that, she authored or co-authored several reports on artists, architects, and policies in support of artistic creation-but these works have never been published (least of all translated in English) or have remained confidential. It was not until 1992, when Moulin had already retired, that she published L'Artiste, l'institution et le marché, the result of a large study on the condition of artists in France carried out-once again with very innovative methodsby the research team at the Centre de Sociologie des Arts in the 1980s. L'Artiste, l'institution et le marché has been republished several times (in paperback this time!) and remains a key reference in France, despite the fact that the data discussed in it were already somewhat obsolete at the time of its first publication. A little while later, in 1995, at a time when the French art world was undergoing a deep crisis, she published De la valeur de l'art, a collection of her articles. Finally, in 2003, her latest work, Le Marché de l'art. Mondialisation et nouvelles technologies, is a rather short book proving that Raymonde Moulin, who was almost 80 years old at the time, was still up to date with developments in the international 
marché et pose de nouveaux jalons pour l'analyse socio-historique de ce monde.

Séverine Sofio

CNRS/Centre de recherches sociologiques et politiques de Paris-Cultures et sociétés urbaines (Cresppa-CSU

\section{Bibliographie indicative de travaux de Raymonde Moulin}

(1961). « Le marchand de tableau ». Journal de Psychologie normale et pathologique, $3: 309-330$

(1963). « Un type idéal, la galerie pilote », $1^{\text {er }}$ Salon international des galeries pilotes de Lausanne. Lausanne, Musée cantonal des Beauxarts : $10-20$

(1964). «Un type de collectionneur : le spéculateur ». Revue française de sociologie, 2 : 155-165.

(1989) [1967]. Le Marché de la peinture en France. Paris, Éditions de Minuit, « Le Sens commun ».

(1969). «Art et société industrielle capitaliste. L'un et le multiple ». Revue française de sociologie, 10(1) : 687-702.

(1971). « Le multiple et ses propriétés ». Revue de l'art, 12 : 75-82.

[et al.] (1973). Les Architectes, métamorphose d'une profession libérale. Paris, Calmann-Lévy.

(1977). Les Aides publiques à la création dans les arts plastiques Danemark, Finlande, France, Grande-Bretagne, Italie, Norvège, PaysBas, RFA, Suède. Paris, La Documentation française. art market. She analyses all the new configurations of the market and prepares the ground for the sociological analysis of this world.

Séverine Sofio

CNRS/Centre de recherches sociologiques et politiques de Paris-Cultures et sociétés urbaines (Cresppa-CSU)

\section{Raymonde Moulin's Selective Bibliography}

(1961). "Le marchand de tableau." Journal de Psychologie normale et pathologique, 3: 309-330.

(1963). "Un type idéal, la galerie pilote." $1^{\text {er }}$ Salon international des galeries pilotes de Lausanne. Lausanne, Musée cantonal des Beaux-arts: 10-20.

(1964). "Un type de collectionneur: le spéculateur." Revue française de sociologie, 2: 155-165.

(1987) [1967]. The French Art Market: A Sociological View. English translation by Arthur Goldhammer. New Brunswick, N. J., Rutgers University Press.

(1969). "Art et société industrielle capitaliste. L'un et le multiple." Revue française de sociologie, 10(1): 687-702.

(1971). "Le multiple et ses propriétés." Revue de l'art, 12: 75-82.

[et al.] (1973). Les Architectes, métamorphose d'une profession libérale. Paris, Calmann-Lévy.

(1977). Les Aides publiques à la création dans les arts plastiques: Danemark, Finlande, France, Grande-Bretagne, Italie, Norvège, PaysBas, RFA, Suède. Paris, La Documentation française. 
(1978). «La genèse de la rareté artistique ». Ethnologie française, 8(23) : 241-258.

(1981). Guide de l'artiste plasticien. Luxembourg, Office des publications officielles des Communautés européennes.

[avec J.-C. Passeron et al.] (1985). Les Artistes : essai de morphologie sociale. Paris, La Documentation française.

(dir.) (1986). Sociologie de l'art, actes du colloque international organisé par la Société française de Sociologie à Marseille les 13-14 juin 1985. Paris, La Documentation française (rééd. 1998, Paris, L'Harmattan).

(1986) « Le marché et le musée. La constitution des valeurs artistiques contemporaines ». Revue française de sociologie, 27(3) : 369-395.

(1992). L'Artiste, l'institution et le marché. Paris, Flammarion (rééd. 1997, 2009).

[avec Alain Quemin] (1993). « La certification de la valeur de l'art. Experts et expertises », Annales ESC, 48(6) : 1421-1445.

[avec Elisabeth Caillet] (1994). « Sociologie de l'art et musée. Un entretien avec Raymonde Moulin ». Publics et Musées, 5 : 100-105

(1995). De la valeur de l'art : recueil d'articles. Paris, Flammarion.

(2000). Le Marché de l'art : mondialisation et nouvelles technologies. Paris, Flammarion (rééd. 2003, 2009).
1978). "La genèse de la rareté artistique." Ethnologie française, 8(2-3): 241-258. Translated in English by Jane Yeoman: (2011). "The Genesis of the Rarity of Art." Art in Translation, 3(4), December: 441-447.

(1981). Guide de l'artiste plasticien. Luxembourg, Office des publications officielles des Communautés européennes.

[avec J.-C. Passeron et al.] (1985). Les Artistes: essai de morphologie sociale. Paris, La Documentation française.

(ed.) (1986). Sociologie de l'art, actes du colloque international organisé par la Société française de Sociologie à Marseille les 13-14 juin 1985 Paris, La Documentation française (rééd. 1998, Paris, L'Harmattan).

(1986) "Le marché et le musée. La constitution des valeurs artistiques contemporaines." Revue française de sociologie, 27(3): 369-395. Translated in English by Michel Vale: (1995) "The Museum and the Marketplace: The Constitution of Value in Contemporary Art." International Journal of Political Economy, 25(2): 33-62.

(1992). L'Artiste, l'institution et le marché. Paris, Flammarion (rééd. 1997, 2009).

[avec Alain Quemin] (1993). "La certification de la valeur de l'art. Experts et expertises », Annales ESC, 48(6): 1421-1445.

[avec Elisabeth Caillet] (1994). "Sociologie de l'art et musée. Un entretien avec Raymonde Moulin." Publics et Musées, 5: 100-105.

(1994). "The Construction of Art Values." International Sociology, 9(1): 5-12.

(2000). Le Marché de l'art: mondialisation et nouvelles technologies. Paris, Flammarion (rééd. 2003, 2009) 